This is Author's Original Version (AOV)

Alpo Honkapohja,

Angus McIntosh Centre for Historical Linguistics,

Dugald Stewart Building, 3 Charles St Ln,

Edinburgh EH8 9AD,

Midlothian,

Scotland

\title{
THE BRIEF RISE AND FALL OF A SUPERSCRIPT ABBREVIATION FOR THE FIRST PERSON SINGULAR PRONOUN IN THE WEST MIDLANDS BETWEEN 1250 AND 1500
}

PALAEOGRAPHY has been defined as 'dating and localizing manuscripts by establishing patterns in the development of characteristic letter forms and abbreviations'. ${ }^{1}$ The traditional means for dating and localising has been archival work by individual scholars who have acquired a high level of familiarity and competence in scribal practices. However, it has also been suggested that these approaches based on the authority of an experienced scholar could be enhanced by more quantitative methods developed for historical dialectology. Wakelin notes the following:

Dialectology can help by identifying spelling patterns, and it might identify variation in script styles as well as in spelling. But so far only a few suggestions have been made, such as a tendency to form $\mathbf{p}$ in different ways in the north and south of England in the fourteenth and

\footnotetext{
${ }^{1}$ K. L. Lowe, 'Palaeography', in L. Brown, editor, Encyclopedia of Language and Linguistics (London: Elsevier, 2006), $2^{\text {nd }}$ edition, 134.
} 
fifteenth centuries. Further local differentiations in script await identification for the thirteenth,

fourteenth, and fifteenth centuries in particular. ${ }^{2}$

One local differentiation in Middle English, which so far has barely attracted scholarly comment, is the strictly regional distribution in a handful of West Midlands counties of the first person singular pronoun, which contracts the spelling $<\mathrm{ich}>$ into a superscript variant $<i^{\mathrm{c}}>{ }^{3}$ The current note describes the provenance and earliest attestations of this abbreviation type in the Linguistic Atlas of Early Middle English (LAEME) and its later provenance in the Linguistic Atlas of Early Mediaeval English $(\mathrm{eLALME}){ }^{4}$

The $\mathrm{i}^{\mathrm{c}}$ abbreviation seems to emerge in the mid-thirteenth century. LAEME includes three scribal texts in which the scribe uses the superscript $\mathrm{i}^{\mathrm{c}}$ abbreviation. These date from between 1250 and 1320 and have been localised in a fairly small geographical area in the West Midlands. The earliest scribal text $(\# 158)^{5}$ is in Oxford, Bodleian Library, Bodley 652, Fols. 1r-10v, which contains Iacob and Iosep, a verse rendering of an Old Testament story in which Joseph is sold into slavery to Egypt. ${ }^{6}$ The poem is the only Middle English item in a tripartite manuscript which also contains Anglo-Norman French and continental French in a variety of hands. Laing (LAEME, 'Index of Sources') describes the hand as 'a neat C13 book hand, with mostly Textura features' and dates it to the third quarter of the thirteenth century. Murdoch places it in the 'mid- to late thirteenth century'. ${ }^{7}$ If Laing's dating is to be trusted, this is the earliest surviving attestation of the superscript $i^{c}$ abbreviation.

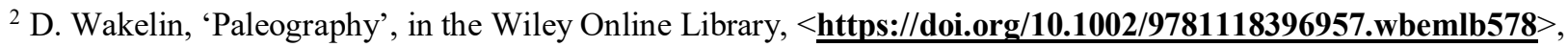
(C) 2017 John Wiley \& Sons, Ltd.

${ }^{3}$ In Middle English, the word was typically spelled $<$ ich $>$, following the post-conquest spelling conventions according to which the palatalised $/ \mathrm{t} / /$ was spelled $<\mathrm{ch}>$. The abbreviation is a type of contraction, which can be defined as 'the omission of one or more letters from the middle of a word'. Superscript letters were 'a form of contraction, whereby the raised position of one or more letters indicated that letters immediately preceding them had been omitted', Anthony G. Petti, English Literary Hands from Chaucer to Dryden (London: Arnold, 1977), 24.

${ }^{4}$ LAEME: M. Laing, A Linguistic Atlas of Early Middle English, 1150-1350, Version 3.2., < http://www.lel.ed.ac.uk/ihd/laeme2/laeme2.html>, (C) The University of Edinburgh. eLALME: M. Benskin, M. Laing, V. Karaiskos and K. Williamson, An Electronic Version of a Linguistic Atlas of Late Mediaeval English, $<$ http://www.lel.ed.ac.uk/ihd/elalme/elalme.html $>$, (C) The University of Edinburgh.

${ }^{5}$ The number in brackets is a reference to the LAEME index of sources.

${ }^{6}$ Digital Index of Middle English Verse number 6688 (Index of Middle English Verse 4172, New Index of Middle English Verse 4172). Another copy of the poem is also in a fragment in Takamiya. The poem was edited by Arthur S. Napier, Iacob and Iosep (Oxford: Clarendon, 1916). Cursor Mundi also contains a version of the story (cf. The Middle English Iacob and Iosep, $\mathrm{x}-\mathrm{xi}$ ).

${ }^{7}$ Brian Murdoch, 'The Middle English Iacob and Iosep and the Medieval Popular Bible', English Studies, xcviii:viii (2017), 826. 
A slightly later scribal specimen containing the abbreviation is found in (\#161) Oxford, Bodleian Library, Additional E.6, which is a roll of four membranes (6 ft x $33 / 8 \mathrm{in}$.). The roll contains four religious poems in English copied by three different hands, one of which, an early cursive Anglicana hand, uses the $\underline{i}^{\mathrm{c}}$ abbreviation. The hand which uses the abbreviation copied two texts: The XV signs before Doomsday $^{8}$ and an Exposition of the Pater Noster. ${ }^{9}$

The third one is (\#286) Cambridge, Corpus Christi College 145, which contains the South English Legendary, a collection of saints' legends and homiletic pieces that survives in several manuscripts. The $i^{c}$ abbreviation is used once by the scribe who copied the main part of the manuscript. This part is copied by a meticulous Anglicana book hand. According to Görlach, the "quality of the script and the carefully planned lay-out suggest production in a large scriptorium' ${ }^{10}$ He dates the manuscript between 1310 and 1320. The three attestations of the superscript $i^{\mathrm{c}}$ in LAEME can thus be dated between 1250 and 1320. All three are in texts which can be classified among the various vernacular verse creations which made biblical stories and other religious content available and accessible to the wider public. ${ }^{11}$

Table 1. The LAEME specimens which include the superscript $\mathrm{i}^{\mathrm{c}}$ abbreviation.

\begin{tabular}{|c|c|c|c|c|c|c|}
\hline Text & $\begin{array}{l}\text { Date, word } \\
\text { count, script }\end{array}$ & $\begin{array}{l}\text { County (grid } \\
\text { reference co- } \\
\text { ordinates) }\end{array}$ & $\begin{array}{l}\text { Word count } \\
\text { (LAEME } \\
\text { tagged } \\
\text { words) }\end{array}$ & Script & $\begin{array}{l}\text { Spelling } \\
\text { variants } \\
\text { of the } 1^{\text {st }} \\
\text { p. } \\
\text { pronoun }\end{array}$ & $\begin{array}{l}\text { Other superscript } \\
\text { abbreviations for function } \\
\text { words }\end{array}$ \\
\hline \# 158 & C13b1 & $\begin{array}{l}\text { NE Gloucs (418 } \\
235)\end{array}$ & 4426 & $\begin{array}{l}\text { A neat C13 book hand, } \\
\text { with mostly Textura } \\
\text { features }\end{array}$ & $\begin{array}{l}\text { ic 40, } \\
\text {-ich 3, } \\
\text {-i 2, } \\
\text { ich 1, } \\
\text {-ic } 1\end{array}$ & $y(a)^{t} 104, y(a)^{t}-i l k e 4$ \\
\hline
\end{tabular}

${ }^{8}$ DIMEV 1309 (IMEV 796, NIMEV 796). The same poem can also be found in Oxford, Bodleian Library Digby 86 (SC 1687), ff. 120v-22v.

${ }^{9}$ DIMEV 3121 (IMEV 1904, NIMEV 1904). This poem is not attested elsewhere. The other two poems, copied by a different hand, are The blessing of heaven king (DIMEV 5215, IMEV 3310, NIMEV 3310) and King of grace and full of pity/Lord of Heaven I-blessed thou be (DIMEV 3000, IMEV 1823, NIMEV 1823).

${ }^{10}$ Manfred Görlach, The Textual Tradition of the South English Legendary (Leeds, 1974), 78.

${ }^{11}$ Murdoch connects Iacob and Iosep to a tradition of popularised Bible paraphrases. The poem contains a number of narratorial references to an implied audience, which may imply an oral delivery by a minstrel or a friar. His interpretation is: 'A possible contextualization might be that the work was originally delivered (by a friar?) to a baronial audience in the house of a lord or a lawgiver' (The Middle English Iacob and Iosep, 863). A similar use has been proposed for the roll \#161, which would have been well suited for the needs of travelling preachers such as friars. See H. G. Pfander, The Popular Sermon of the Medieval Friar in England (PhD diss., New York University, 1937), 60-9. 


\begin{tabular}{|c|c|c|c|c|c|c|}
\hline \# 161 & $\mathrm{C} 13 \mathrm{~b} 2$ & $\begin{array}{l}\text { Gloucs (but language } \\
\text { may be somewhat } \\
\text { mixed) } \\
(387229)\end{array}$ & 1664 & Early cursive Anglicana & $\begin{array}{l}\text { y } 3, \\
\text { ic } 2, \\
\text { ich } 1\end{array}$ & $\begin{array}{l}y(a)^{t} 43, f(r)^{a} m 3, y(a)^{t}-11 k e \\
3, \text { aftir-y(a)t } 1 \text { so-y(a)t } 1\end{array}$ \\
\hline \# 286 & $\begin{array}{l}\text { C14a1 } \\
\text { (ca1310-20) }\end{array}$ & NW Berks (429 195) & 29842 & Anglicana & $\begin{array}{l}\text { ich } 216, \\
\text { ich- } 69, \\
\text { i- } 34, \\
\text { i } 6, \\
\text { ic } 1, \\
\text { hi } 1, \\
\text { ihc } 1, \\
\text { y } 1 \\
\text { ych } 1\end{array}$ & $\begin{array}{l}y(a)^{t} 551, q(u)^{a} y 110, f(r)^{a} m \\
51, \text { so- y(a)t } 17, y^{u} 6, \text { aftir- } \\
y(a)^{t} 1, \text { dai- y(a) } 1, \text { a3en- } \\
y(a)^{t} 1, \text { biuore- y(a) } 1, \\
f(r)^{\mathrm{a} m} \text {-ward } 1, f(r)^{\mathrm{a}} \text { mward } 1, \\
\text { wane-y(a) } 1, \text { yer-f(r) }{ }^{\mathrm{a}} \mathrm{m} 1\end{array}$ \\
\hline
\end{tabular}

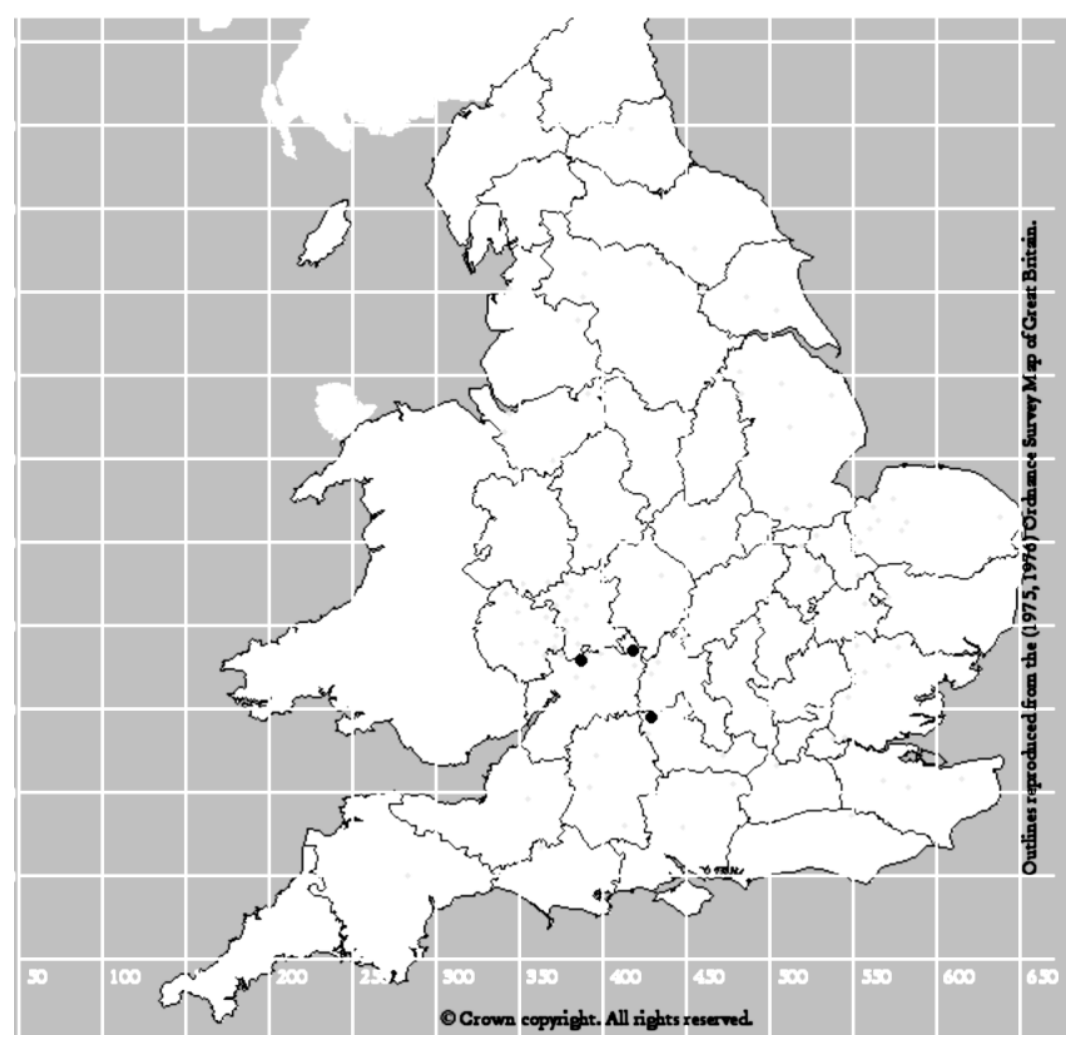

Fig. 1. The areal distribution of the superscript $i^{c}$ abbreviation in LAEME, 1250-1320.

What is very interesting about all of these specimens is that they show a tight clustering in the west Midlands. Two of the scribal texts have been localised in Gloucestershire and one in the northwest corner of Berkshire. The ones in Gloucestershire include the earliest attestation (\#158), which was 
originally localised as a part of LALME, but later included in LAEME rather than eLALME. It also includes \#161, which is localised in this area, but according to notes by Laing may contain some degree of linguistic mixture with the two other hands in the same manuscript, which have been localised in Essex. ${ }^{12}$ Text \#286, on the other hand, has been localised in the northwest corner of Berkshire in LAEME, but was earlier localised in Gloucestershire or Worcestershire. ${ }^{13}$ Together the LAEME localisations form a triangle which has its middle in Gloucestershire, but the individual localisations are also close to the borders of Worcestershire, Warwickshire, Oxfordshire, Berkshire and Wiltshire.

The clustering remains similar, but broader in the period 1350 to 1450 covered by eLALME. Some variant of the abbreviated first person pronoun is attested in altogether 25 Linguistic Profiles (LPs). ${ }^{14}$ Eleven of these have been localised in Gloucestershire. Others have been localised in its close vicinity to Herefordshire, Wiltshire or Somerset, but near the border of Gloucestershire. There are, however, also attestations further south extending from Devon to Hampshire, and a single attestation in a LP localised in Essex.

Table 2. eLALME linguistic profiles containing the superscript $\mathrm{i}^{\mathrm{c}}$ abbreviation.

\begin{tabular}{|l|rr|}
\hline Counties: & Number of LPs \\
\hline Gloucestershire & 11 \\
\hline Wiltshire & 4 \\
\hline Somerset & 3 \\
\hline Devon & 2 \\
\hline Herefordshire & 2 \\
\hline Essex & 1 \\
\hline Hampshire & & 2 \\
\hline
\end{tabular}

${ }^{12}$ Murdoch (The Middle English Iacob and Iosep, 546) is suspicious of the localising of \#158 to North-East Gloucestershire and says, '[t]he dialect is unclear; Napier goes no further than placing it in the South-West, although (North-East) Gloucestershire and other areas have been suggested'.

${ }^{13}$ Laing (LAEME, 'Index of Sources') notes a personal communication with M. L. Samuels, according to whom the language is South Worcestershire, not far from the border of Gloucestershire. However, Laing also mentions names on the manuscript's first flyleaf which 'show C16 connections with places in Gloucs'.

14 The LPs are Gloucestershire: 6980, 6990, 7000, 7020, 7040, 7052, 7080, 7110, 7130, 7151, 7170, 7180, 7230; Wiltshire 5300, 5371, 5411, 5450; Somerset 5200, 5281, 5300; Devon 5051, 5112; Herefordshire 7320, 7430; Essex 6340; and Worcestershire 7660. It has to be noted though that the form was only collected for Southern and Irish part of the atlas. 


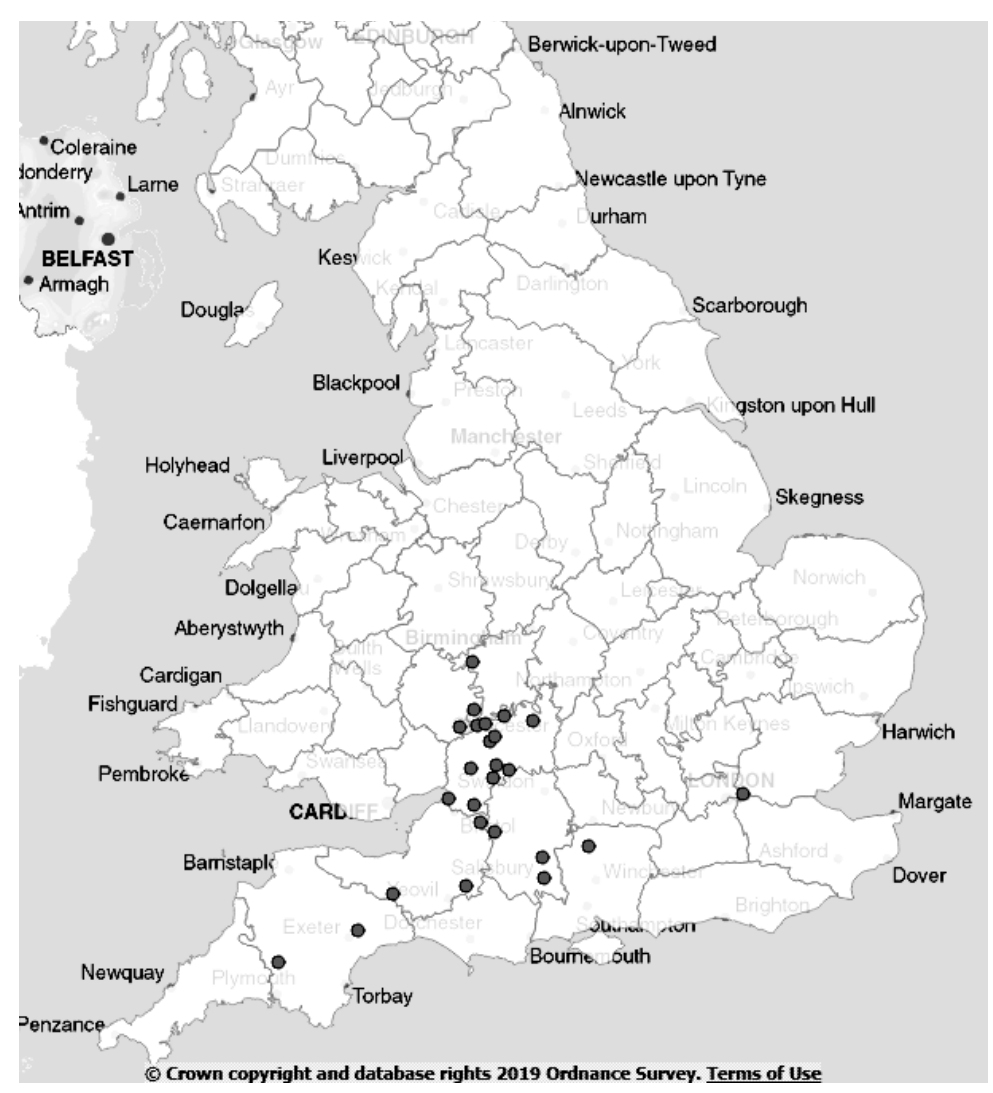

Fig. 2. The areal distribution of superscript $\mathrm{i}^{\mathrm{c}}$ variants in eLALME, 1350-1450.

The West Midlands had importance both for trade and warfare in the high and late Middle Ages.

Gloucestershire had two major towns, Gloucester and Bristol, which were major centres of trade. ${ }^{15}$ The shire also had strategic importance because of Norman and Plantagenet interests regarding Wales. The area also has a number of important religious houses, including the Benedictine monasteries of Gloucester, Tewkesbury and Winchcombe. ${ }^{16}$

The West Midlands are known for their unusually lively literary culture in the early Middle English period. In particular, they are known for the so-called AB language, which is connected with the Ancrene Wisse and the related Katherine and Wooing groups. ${ }^{17}$ Moreover, the so-called Tremulous Hand

\footnotetext{
${ }^{15}$ I have consulted the matter with Moragh Gordon, the author of The Urban Vernacular of Late Medieval and Renaissance Bristol (PhD diss., Utrecht University, 2017). The abbreviation was not found in her earliest data, a corpus Briston council ordinances between 1400 and 1450, but first person pronouns are very rare in the text type. ${ }^{16}$ British History Online (BHO), Gloucester, $<\underline{\text { https: } / / \text { www.british-history.ac.uk/vch/glos/vol4 >. }}$

${ }_{17}$ For the AB language, see Merja Black [Stenroos], 'AB or simply A? Reconsidering the case for a standard', Neuphilologische Mitteilungen, c (1999), 155-74; Jeremy. J. Smith, ‘Standard language in early Middle English', in
} 
of Worcester was active in the northern neighbouring county. Two abbreviation types have a similar provenance, including short 9 -forms (무 'thus', $\underline{\text { hq }}$ 'house' and $\underline{\mathrm{sp}_{9}}$ 'spouse') and a thorn abbreviation with a bar through its descender ( $\mathrm{b}$ for 'through') ${ }^{18}$ However, there are also differences: the AB language has been seen as a surviving example of the influence of Old English orthographic practices in the Early Middle English period and the Tremulous Hand is famous for his use of Old English manuscripts. The emergence of a new superscript abbreviation, on the other hand, seems to be part of the mid-thirteenth century change and expansion of written culture.

There is a definite increase in the new superscript abbreviations for function words occurring after $1250 .{ }^{19}$ Prior to that date the most common types of superscript abbreviation are for lexical words, such as $\underline{c}^{\mathrm{i}} \mathrm{st}$ 'christ' or pison 'prison', but a set of function word abbreviations overtake them in frequency after 1250. In all three of the specimens the superscript $i^{c}$ abbreviation occurs with superscript $\underline{b}^{t}$ 'that', which emerged around the same time. These specimens also contain $\underline{f}^{\mathrm{a} m}$ 'from' and $\mathrm{y}^{\mathrm{u}}$ 'thou' and a number of combined forms such as aftir-y 'after that' or yer-fa $m$ 'therefrom' (see Table 1 above).

The emergence of new vernacular superscript abbreviations for function words corresponds with changes that were in progress in the thirteenth century. This century saw an increase in written culture: the use of written administration spread from religious communities and royal administration to the gentry and even peasants. New uses such as private study and meditation led to a decrease in the size of books. ${ }^{20}$ At the same time, quicker copying led to the emergence of a new cursive hand, dubbed Anglicana by Parkes (English Cursive Book Hands), who dates its rise from the mid thirteenth century to until about $1325 .{ }^{21}$ It seems quite likely that as abbreviations were needed for saving space and time (as dictation was a common method of composition) - and they were used for words that came frequently

Irma Taavitsainen, Terttu Nevalainen, Päivi Pahta and Matti Rissanen, editors, Placing Middle English in Context (Berlin: Mouton, 2000), 125-39.

${ }^{18}$ I discuss the provenance of these types in a forthcoming paper: Alpo Honkapohja, 'Anchorites and Abbreviations: a corpus study of abbreviations of Germanic and Romance lexicon in the Ancrene Wisse', in Merja Stenroos, Martti Mäkinen, Kjetil V. Thengs and Oliver M. Traxel, editors, Current Explorations in Middle English (Frankfurt: Peter Lang).

${ }^{19}$ Superscript abbreviations themselves were not new. For Latin examples of superscript abbreviations used by both Anglo-Saxon and Norman scribes see N.R. Ker, English Manuscripts in the Century after the Norman Conquest, (Oxford: Clarendon, 1960), plates 1-3.

${ }^{20}$ M.T. Clanchy, From Memory to Written Record, England 1066-1307 (Cambridge: Harvard, 1977), 38, 105.

${ }^{21}$ M.B. Parkes, English Cursive Book Hands 1250-1500 (Oxford: Scolar, 1969), xv. 
under the pen such as pronouns and prepositions. ${ }^{22}$ However, unlike some other superscript abbreviations,

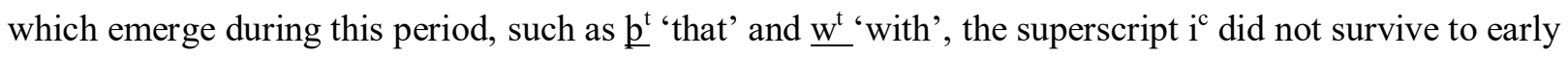
printed books and beyond. The likely reason is, of course, related to the development of the forms of the first person pronoun that did not require abbreviation.

The spellings for the first person pronoun found in the LAEME specimen and eLALME LPs display much variation, characteristically for Middle English and language change in progress (see Table 1 above and Table 3 below). The variant spellings for the first-person pronoun can be classified into four groups: 1) short I-spellings ( $<\mathrm{y}>,<\mathrm{i}>,<\mathrm{I}>), 2)$ longer ich-spellings ( $<\mathrm{ich}>,<\mathrm{ych}>,<\mathrm{ihc}>,<\mathrm{iche}>), 3)$ abbreviated spellings $\left(<\mathrm{i}^{\mathrm{c}}>,<\mathrm{y}^{\mathrm{c}}>,<\mathrm{y}^{\mathrm{c}}>\right)$ and 4$)$ assimilated spellings $(<$ nellic $>,<$ nellich $>,<$ haddich $>$, $<$ seidich $>,<$ telli $>,<$ nabbi $>,<$ ichelle $>,<$ ichot $>,<$ icham $>,<$ ycham $>,<$ ych-am $>,<$ icchulle $>,<$ ichote $>$, $<$ ychshal $>$ ). The division between short and long spellings is likely to correspond with a division between stressed and unstressed variants of the personal pronoun. The consonant was lost in the North and Midlands around 1200, where $<\mathrm{y}>$ or $<\mathrm{i} / \mathrm{I}>$ became the only forms by around 1400 , whereas in southern texts stressed $<i$ ich $>$ spellings were used before vowels or $\underline{h}$ and remained in use until the end of the Middle English period. ${ }^{23}$ They were, however, eventually lost and with them the need to abbreviate the first person pronoun, as a single letter does not require shortening.

To conclude, the abbreviation used for $\mathrm{i}^{\mathrm{c}}$ developed in the West Midlands in the mid-thirteenth century. Unlike some of its cousins, it proved to be a phenomenon with a limited life span, but it does provide further support for the idea that there are orthographic practices with a strictly local distribution to be discovered. With increasingly better digital resources there are many things to find. What I have previously found in my work is that many abbreviation practices are connected to the West Midlands, including the earliest attestations of the much more influential superscript $\mathrm{p}^{\mathrm{t}}$ 'that'. Further work is needed to understand the importance of unique abbreviation practices in the West Midlands. Notwithstanding, discoveries like this show that there is still much we do not know about what is going on and that historical dialectology and quantitative approaches can indeed complement palaeography.

\footnotetext{
${ }^{22}$ Geneviève Hasenohr, 'Écrire en latin, écrire en roman: réflexions sur la pratique des abréviations dans les manuscrits français des XII ${ }^{\mathrm{e}}$ et XIII' ${ }^{\mathrm{e}}$ siècles', in Michel Banniard, editor, Langages et peuples d'Europe (CNRS Université de Touloise-Le Mirail), 79-110.

${ }^{23}$ R.D. Fulk, Introduction to Middle English: Grammar, Texts (Toronto: Broadview, 2013), §54.
} 
Angus McIntosh Centre for Historical Linguistics, University of Edinburgh

Table 3. The linguistic profiles in eLALME that contain some variant of the superscript $\mathrm{i}^{\mathrm{c}}$ abbreviation.

\begin{tabular}{|c|c|c|c|}
\hline LP & Text & Localisation & Forms (LALME item number) \\
\hline 5051 & $\begin{array}{l}\text { Seege or Batayle of Troye. Ed. Barnicle, The } \\
\text { Seege or Batayle of Troye, EETS OS } 172\end{array}$ & Devon & $\begin{array}{l}\text { 178: y ((I)), } \\
\text { 178-20: y (I) }\left(\left(y^{c}\right)\right) \\
\text { 178-30: y } \\
\text { 178-40: y-am, } y^{c}-a m \text { (3e-am, I-am, } \\
\left.I^{c}-a m\right)\end{array}$ \\
\hline 5112 & Partial draft of Sir Ferumbras & Devon & $\begin{array}{l}\text { 178: y ((I, Ich, i, ich, ic })) \\
\text { 178-20: y ((ich)) } \\
\text { 178-30: y, ich, ic } \\
\text { 178-40: ic-am, ich-am, y-am }\end{array}$ \\
\hline 6340 & Orison of the Five Joys & Essex & 178: ich $\left(\mathrm{i}, \mathrm{i}^{\mathrm{c}}, \mathrm{y}\right)$ \\
\hline 7052 & $\underline{\text { Polychronicon }}$ & Gloucestershire & $\begin{array}{l}\text { 178: ic, ich, y (ych) } \\
\text { 178-20: ich } \\
\text { 178-30: ich } \\
\text { 178-40: ic-am }\end{array}$ \\
\hline 7180 & $\begin{array}{l}\text { South English Legendary Ed. C. Horstmann, } \\
\text { Archiv } 57 \text { (1877) }\end{array}$ & Gloucestershire & 178: $y+n$, ich, ich-, $i^{c}(I+n)$ \\
\hline 7170 & South English Legendary & Gloucestershire & 178: $\mathrm{i}^{\mathrm{c}}(\mathrm{I}+\mathrm{n}, \mathrm{Ich}-)$ \\
\hline 7080 & London, British Library, Harley 201 & Gloucestershire & $\begin{array}{l}\text { 178: ych }(y+n-)\left(\left(\operatorname{Ich}, y^{c}\right)\right) \\
178-20: y c h \\
\text { 178-30: ych-, ych } \\
\text { 178-40: ycham }\end{array}$ \\
\hline 6990 & The Southern Passion, EETS OS 169 & Gloucestershire & 178: ich $\left(\mathrm{y}+\mathrm{n}, \mathrm{I}+\mathrm{n}, \mathrm{i}^{\mathrm{c}}\right)$ \\
\hline 6980 & $\underline{\text { Prick of Conscience }}$ & Gloucestershire & 178: I, ich $\left(y, i^{c}\right)$ \\
\hline 7040 & Prick of Conscience & Gloucestershire & $178: \mathrm{i}^{\mathrm{c}}(\mathrm{I})$ \\
\hline 7230 & Piers Plowman C-version & Gloucestershire & 178: y, ý (I) \\
\hline 7020 & South English Legendary & Gloucestershire & 178: ic ich (y+n, ihc, ich-) \\
\hline
\end{tabular}




\begin{tabular}{|c|c|c|c|}
\hline 7151 & recipes, alchemica etc. & Gloucestershire & $\begin{array}{l}178: y c h, y^{c}, y \\
178-20: y^{c}, i^{c}\end{array}$ \\
\hline 7000 & Prick of Conscience & Gloucestershire & 178: y, I, i ${ }^{\mathrm{c}}$ \\
\hline 7130 & South English Legendary & Gloucestershire & 178: ich-, i+n, ic, ich (i-) \\
\hline 7110 & $\underline{\text { Southern Legendary }}$ & Gloucestershire & 178: ich, ich- (ic ${ }^{c}$, icchulle) \\
\hline 5470 & South English Legendary & Hampshire & 178: I, ic ich \\
\hline 7320 & Piers Plowman C-version & Herefordshire & 178: y, I ((i, Iche, ic $))$ \\
\hline 7430 & South English Legendary & Herefordshire & $\begin{array}{l}\text { 178: Ich, ic (iche, ich) ((i, y, I, } \\
\text { I+chote, }-y))\end{array}$ \\
\hline 9390 & Prick of Conscience & Somerset & $178: i^{c}, y, y^{c}$ \\
\hline 5200 & $\underline{\text { Seven Penitential Psalms }}$ & Somerset & 178: y $\left(\left(i^{\mathrm{c}}, \mathrm{y}^{\mathrm{c}}, \mathrm{ych}+\mathrm{shal}\right)\right)$ \\
\hline 5281 & $\begin{array}{l}\text { a compilation of historical, legal and } \\
\text { ecclesiastical material in Latin, French and } \\
\text { English, made at Bath Priory } 1412-28\end{array}$ & Somerset & $\begin{array}{l}\text { 178: } y\left(\left(y c h, y^{c}\right)\right) \\
178-20: y\left(\left(y^{c}, y c h\right)\right) \\
178-30: y\left(y^{c}\right) \\
178-40: y-a m(y c h-a m)\end{array}$ \\
\hline 5300 & $\begin{array}{l}\text { Short Metrical Chronicle, and Robert of } \\
\text { Gloucester's Chronicle }\end{array}$ & Wiltshire & 178: $\mathrm{i}^{\mathrm{c}}(\mathrm{ich}, \mathrm{y}+\mathrm{sch}, \mathrm{i}+\mathrm{sch}, \mathrm{I}+\mathrm{ne})$ \\
\hline 5371 & Three hands in similar language & Wiltshire & 178: ych (I, ic , ich, y) \\
\hline 5450 & $\underline{\text { Prick of Conscience }}$ & Wiltshire & 178: $y^{\mathrm{c}}(\mathrm{ych})$ \\
\hline 5411 & $\begin{array}{l}\text { Robert of Gloucester's Chronicle, ed. T. } \\
\text { Hearne (Oxford: At the Theater, } 2 \text { vols., 1724) }\end{array}$ & Wiltshire & $\begin{array}{l}\left.\left.\text { 178: ich, y ((Ich, ic } \mathrm{y}^{\mathrm{c}}, \mathrm{ych}, \mathrm{I}\right)\right) \\
\text { 178-20: ich }((\mathrm{y}, \mathrm{Ich}, \mathrm{I})) \\
\text { 178-30: ich, y, I } \\
\text { 178-40: y-am }\end{array}$ \\
\hline 7660 & Prick of Conscience & Worcestershire & 178: y (i, ich, ic) ((ych)) \\
\hline
\end{tabular}

